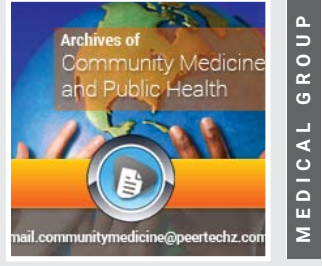

\title{
Suggestion of Terminology in COVID-19
}

\section{Li Liư ${ }^{1}$ and Yumin Huang-Link ${ }^{2 *}$}

${ }^{1}$ Medical College of Wuhan University of Science and Technology, Wuhan, 430081, China

${ }^{2}$ Department of Neurology, Linkoping University Hospital, Linkoping City, Sweden

\section{Opinion}

Scientists and medical doctors have been contributing largely to identify novel coronavirus 2 as the cause of the severe acute respiratory syndrome (SARS-COV-2) which emerged in large numbers of infected people in Wuhan City since Dec. 2019 [1-3]. Scientists quickly sequenced SARS-COV-2 and shared their knowledge with the world [3,4]. Searching for vaccine and specific therapy is the next global public health concern to prevent future spreading [5]. The new research, clinical and epidemiological data on SARS-COV-2 are continuing to explode. We need to make consensus to use terminology in SARS-COV-2 studies correctly and precisely.

Coronavirus (COVs) is one of major viruses that primarily targets the human respiratory system. Previous COV outbreaks were seen in SARS 2003 in Asia, and Middle East respiratory syndrome (MERS) 2012. Acute respiratory illness has been dominant in COVs caused diseases with fever, cough, sore throat, breathlessness, fatigue, malaise [4]. In the case of COV2 the clinical feature is similar. Patients with clinical symptoms and SARS-COV-2 positive are diagnosed as coronaviruses disease 2019 (COVID-19). But with the increasing test of naso-pharyngeal swab we realize that people with SARSCOV-2 positive can be asymptomatic. This group may be defined as SARS-COV-2 carrier. On the other hand, people with SARS-COV-2 negative can have typical COVID-19 clinical manifestation, the chest $\mathrm{X}$-ray showing bilateral infiltrates and laboratory features with increased levels of C-reactive protein (CRP), inflammatory cytokines like interleukin-6, ferritin, D-dimer, neutrophilia and lymphocytopenia. Such cases may be defined as suspected COVID-19. The COVID-19 can behavior with encephalitis, polycranial neuritis, MillerFisher syndrome, Guillain-Barré Syndrome, cytokine release syndrome, endo-carditis or multiorgan etc [5,6], these groups may be defined as SARS-COV-2 syndrome. If there
Received: 14 September, 2020

Accepted: 05 October, 2020

Published: 06 October, 2020

*Corresponding author: Yumin Huang-Link, Department of Neurology, Linkoping University Hospital, Linkoping City, Sweden,

E-mail:Yumin.link@regionostergotland.se

https://www.peertechz.com

\section{Check for updates}

is an evidence of lower respiratory tract involvement with abnormal chest X-ray or CT scans, the COVID-19 pneumonia or severe acute respiratory syndrome coronavirus 2 (SARSCoV-2) should be applied to indicate severe consequence with possible respiratory failure $[2-4,7]$.

In Europe or the United States, there is increased evidence that COVID-19 can behavior with olfactory reduction, diarrhea, encephalitis, endo-carditis or multiorgan failure with or without SARS-COV-2 symptoms [8]. In such cases differential diagnoses is urged clinically. These patients should be treated in isolation until COV-2 and other relevant laboratory tests have been performed and interpreted correctly before the patients are moved out from the COVID-19/Pandemic unit.

In summary, COVID-19 serves as general diagnosis to define COV-2 related symptoms including SARS-COV-2. SARS-COV-2 is specifically applied to indicate severe acute respiratory syndrome caused by COV-2. Those who have typical COVID-19 features without positive COV-2 may be defined as suspected COVID-19. Those who have no symptoms but positive COV-2 may be defined as COV-2 carrier. Certainly, future combination of antibody (IgG and IgM against COV-2) test and COVID-19 antigen rapid test will broaden diagnosis and prognosis of COVID-19.

\section{Acknowledgement}

We are thankful for revision and import from Prof. Hans Link, Dept of Neurosciences, Karolinska Institute, Stockholm, Sweden.

\section{References}

1. Wu Z, McGoogan JM (2020) Characteristics of and Important Lessons From the Coronavirus Disease 2019 (COVID-19) Outbreak in China: Summary of a Report of 72314 Cases From the Chinese Center for Disease Control and Prevention. JAMA 323: 1239-1242. Link: https://bit.ly/33ugatq 
2. Huang C, Wang Y, Li X, Ren L, Zhao J, et al. (2020) Clinical features of patients infected with 2019 novel coronavirus in Wuhan, China. Lancet 395: 497-506. Link: https://bit.ly/2HXPUPX

3. Zhai P, Ding Y, Wu X, Long J, Zhong Y, et al. (2020) The epidemiology, diagnosis and treatment of COVID-19. Int J Antimicrob Agents 55: 105955. Link: https://bit.ly/30xGZv5

4. Chen H, Guo J, Wang C, Luo F, Yu X, et al. (2020) Clinical characteristics and intrauterine vertical transmission potential of COVID-19 infection in nine pregnant women: a retrospective review of medical records. Lancet 395: 809815. Link: https://bit.ly/3jwmsOZ

5. Moore JB, June $\mathrm{CH}$ (2020) Cytokine release syndrome in severe COVID-19. Science 368: 473-474. Link: https://bit.ly/3jwUClJ
6. Gutiérrez-Ortiz C, Méndez A, Rodrigo-Rey S, San Pedro-Murillo E, BermejoGuerrero L, et al. (2020) Miller Fisher Syndrome and polyneuritis cranialis in COVID-19. Neurology 95. Link: https://bit.ly/30A1g2T

7. Wong HYF, Lam HYS, Fong AH, Leung ST, Chin TW, et al. (2020) Frequency and Distribution of Chest Radiographic Findings in Patients Positive for COVID-19. Radiology 296: E72-E78. Link: https://bit.ly/34kLGcE

8. Helms J, Kremer S, Merdji H, Clere-Jehl R, Schenck M, et al. (2020) Neurologic Features in Severe SARS-CoV-2 Infection. N Engl J Med 382: 2268-2270. Link: https://bit.ly/36xaYXD
Discover a bigger Impact and Visibility of your article publication with

Peertechz Publications

\section{Highlights}

* Signatory publisher of ORCID

- Signatory Publisher of DORA (San Francisco Declaration on Research Assessment)

* Articles archived in worlds' renowned service providers such as Portico, CNKI, AGRIS, TDNet, Base (Bielefeld University Library), CrossRef, Scilit, J-Gate etc.

* Journals indexed in ICMJE, SHERPA/ROMEO, Google Scholar etc.

* OAI-PMH (Open Archives Initiative Protocol for Metadata Harvesting)

* Dedicated Editorial Board for every journa

* Accurate and rapid peer-review process

* Increased citations of published articles through promotions

* Reduced timeline for article publication

Submit your articles and experience a new surge in publication services

(https://www.peertechz.com/submission).

Peertechz journals wishes everlasting success in your every endeavours.

Copyright: $\odot 2020$ Liu L, et al. This is an open-access article distributed under the terms of the Creative Commons Attribution License, which permits unrestricted use, distribution, and reproduction in any medium, provided the original author and source are credited. 